\title{
PENGARUH REKRUTMEN DAN PELATIHAN TERHADAP KINERJA GURU SD, SMP, SMA SAINT JOHN HARAPAN INDAH DI KOTA BEKASI
}

\author{
Gerson Junius Arisom $^{[1]}$ Ignatius Ario Sumbogo $^{[2]}$ \\ Prodi Manajemen, Institut Teknologi dan Bisnis Kalbis \\ Jalan Pulomas Selatan Kav. 22, Jakarta Timur 13210 \\ Email: juniusgersonarisom@gmail.com \\ Dosen Prodi Manajemen, Institut Teknologi dan Bisnis Kalbis \\ Email: ignatius.sumbogo@kalbis.ac.id
}

\begin{abstract}
This study aims to determine the positive and significant effect of recruitment and training on teacher performance in elementary, junior high, and high school Saint John Harapan Indah Bekasi. This research uses quantitative descriptive approach through survey and data retrieval technique is non probability sampling with saturation sampling method to 50 teachers. The result of this research indicates that the recruitment variable is not Have a significant effect to performance variable and training variable have an effect on signifikan to performance variable.
\end{abstract}

Keywords: recruitment, training, performance, teacher.

Abstrak: Penelitian ini bertujuan untuk mengetahui pengaruh positif dan signifikan rekrutmen dan pelatihan terhadap kinerja guru di SD, SMP, dan SMA Saint John Harapan Indah Bekasi. Penelitian ini menggunakan pendekatan deskriptif kuantitatif melalui survei dan teknik pengambilan data adalah non probability sampling dengan metode saturation sampling kepada sebanyak 50 guru. Hasil dari penelitian ini menunjukkan bahwa variabel rekrutmen tidak berpengaruh signifikan terhadap variabel kinerja dan variabel pelatihan berpengaruh signifikan terhadap variabel kinerja.

Kata kunci: rekrutmen, pelatihan, kinerja, guru. 


\section{PENDAHULUAN}

Guru adalah salah satu faktor penting yang tidak dapat dilepaskan dari sebuah yayasan pendidikan atau sekolah karena menjadi kunci yang menentukan perkembangan sekolah. Dalam konteks sumber daya manusia, guru adalah manusia yang dipekerjakan oleh sekolah untuk mencapai tujuan sekolah. Perkembangan manajemen mengubah posisi guru, tidak semata sumber daya belaka, melainkan modal atau aset bagi yayasan atau sekolah atau dikategorikan sebagai human capital. Hal ini berarti bahwa Sumber Daya Manusia (SDM) dilihat bukan sekadar aset, tetapi aset yang bernilai dan dapat dilipatgandakan (bandingkan dengan portfolio investasi) serta dimaknai bukan sebagai beban atau liability (cost). Hal ini menandaskan perspektif SDM sebagai investasi bagi institusi atau organisasi.

Manajemen SDM (MSDM) dapat diartikan sebagai pendayagunaan sumber daya manusia di dalam organisasi, yang dilakukan melalui fungsi- fungsi perencanaan SDM, rekrutmen dan seleksi, pengembangan sumber daya manusia, perencanaan dan pengembangan karir, pelatihan, pemberian kompensasi dan kesejahteraan, keselamatan dan kesehatan kerja dan hubungan industrial. Setiap perusahaan tentunya ingin mendapatkan sumber daya manusia yang mampu membantu perusahaan untuk mencapai tujuan, sama halnya seperti Sekolah Kristen Saint John Harapan Indah Bekasi. Yayasan pendidikan yang bertempat di Jalan Kemuning Indah IV Blok $\mathrm{HH}$ ini didirikan pada tahun 1995, dimulai dari $\mathrm{KB}, \mathrm{TK}$, dan $\mathrm{SD}$, sebelum membangun Sekolah Menengah Pertama pada tahun 2004 dan mendirikan Sekolah Mengengah Atas di tahun 2012. Saat ini, Saint John Harapan Indah sudah memiliki jenjang yang lengkap mulai dari $\mathrm{KB}$, TK, SD, SMP, dan SMA.

Sebagaimana perusahaan, sebuah yayasan juga butuh sumber daya manusia yang baik, yang sesuai dengan keinginan yayasan tersebut. Ada beberapa tahap yang harus 
dijalankan perusahaan untuk mendapatkan karyawaan atau guru yang kompeten. Proses untuk mendapatkan karyawan akan dimulai dari proses rekrutmen.

merupakan Rekrutmen serangkaian aktivitas mencari dan memikat (attract) pelamar kerja dengan motivasi, kemampuan, keahlian, dan pengetahuan yang diperlukan untuk menutupi kekurangan yang diidentifikasikan dalam perencanaan kepegawaian. Hasil yang didapatkan dari proses rekrutmen adalah sejumlah tenaga kerja yang akan memasuki proses seleksi, yakni proses untuk menentukan kandidat yang mana yang paling layak untuk mengisi jabatan tertentu yang tersedia di perusahaan.

Proses rekrutmen sudah dijalankan dengan prosedur tetap selama beberapa tahun di Sekolah Saint John Harapan Indah. Tetapi, proses rekrutmen di Sekolah Saint John Harapan Indah masih dirasa memiliki beberapa persoalan dan dapat dinilai belum maksimal. Salah satu catatan untuk bidang rekrutmen adalah soal kesesuaian antara bidang kompetensi guru-guru SD, SMP, dan SMA, dengan tanggungjawab pengajaran dan pembinaan yang mereka terima. Kondisi ini mengacu pada aturan Undang-Undang Nomor 14, Pasal 1 tahun 2005, tentang kompetensi dasar Guru SD yang disyaratkan yakni dengan kewajiban memiliki ijazah Pendidikan Guru Sekolah Dasar (PGSD).

Kementerian Pendidikan dan Kebudayaan (Kemendikbud) hanya memberikan Tunjangan Profesi Pendidik (TPP) selama dua tahun saja. Ketentuan pencairan TPP bagi guru SD itu tertuang dalam Permendikbud no.62 tahun 2013 tentang Sertifikasi Guru dalam Jabatan untuk Penataan Guru. Dalam pasal 5 peraturan itu disebutkan, bahwa guru yang dipindahkan tugas tidak sesuai dengan sertifikat profesinya, hanya berhak mendapatkan TPP selama dua tahun.

Pada praktiknya, para guru di SD Saint John Harapan Indah masih banyak yang belum memiliki ijazah PGSD. Peneliti 
telah membuat rekap data jabatan di sekolah tersebut, sekunder guru SD Saint John yang dapat dilihat di tabel 1.1 Harapan Indah lengkap dengan berikut ini : pendidikan terakhir serta

Tabel 1. Data Kelayakan Guru SD Kelas I,

\begin{tabular}{|c|c|c|c|c|c|c|c|}
\hline $\begin{array}{l}\mathrm{N} \\
\mathrm{O}\end{array}$ & Nama Guru & Jabatan & $\begin{array}{l}\text { Pendidikan } \\
\text { Terakhir }\end{array}$ & Keterangan & $\begin{array}{l}\text { II, IV, V, } \\
\text { VI }\end{array}$ & & \\
\hline 1 & $\begin{array}{l}\text { Izaak } \\
\text { Domingus } \\
\text { Lainsamputt } \\
\text { y }\end{array}$ & $\begin{array}{l}\text { Kepala } \\
\text { Sekolah }\end{array}$ & $\begin{array}{l}\text { S1 Teknik } \\
\text { Kelautan }\end{array}$ & Tidak Layak $_{2}^{\text {Chris Natali }}$ & $\begin{array}{l}\text { Guru } \\
\text { Olahraga } \\
\text { Kelas I- } \\
\text { VI } \\
\end{array}$ & $\begin{array}{ll}\text { S1 } & \text { PGSD } \\
2016 & \end{array}$ & Tidak Layak \\
\hline 2 & $\begin{array}{l}\text { Ervina } \\
\text { Kasminah }\end{array}$ & $\begin{array}{l}\text { Wali } \\
\text { Kelas V } \\
\text { B }\end{array}$ & $\begin{array}{ll}\text { S1 } & \text { PGSD } \\
2008 & \end{array}$ & \begin{tabular}{l|l} 
Layak & Nolita \\
& Agustini \\
& Pardede \\
\end{tabular} & $\begin{array}{ll}\text { Wali } & \\
\text { Kelas IV } \\
\text { B } \\
\end{array}$ & $\begin{array}{l}\text { S1 FKIP B. } \\
\text { Inggris } 2004\end{array}$ & Tidak Layak \\
\hline 3 & Evie Djauri & $\begin{array}{l}\text { Wali } \\
\text { Kelas II } \\
\text { A \& B } \\
\end{array}$ & SPG '73 & \begin{tabular}{l|ll} 
Layak & Helda & Mega \\
& 4 & Wati
\end{tabular} & $\begin{array}{l}\text { Wali } \\
\text { Kelas III } \\
\text { B } \\
\end{array}$ & $\begin{array}{l}\text { S1 Psikologi } \\
\text { Pend. BK } \\
2009\end{array}$ & Tidak Layak \\
\hline 4 & $\begin{array}{l}\text { Magdalena } \\
\text { F. Lembong }\end{array}$ & $\begin{array}{ll}\text { Wali } & \\
\text { Kelas } & \text { VI } \\
\text { A } \quad \& \\
\text { Koordinat }\end{array}$ & $\begin{array}{ll}\text { S1 } & \text { PGSD } \\
2009 & \end{array}$ & \begin{tabular}{l|ll} 
Layak & \multicolumn{1}{|c}{ Yublina } \\
& 5 & Dewi Yanti \\
& Bole
\end{tabular} & $\begin{array}{l}\text { Guru } \\
\text { Agama } \\
\text { Kelas III- } \\
\text { VI } \\
\end{array}$ & $\begin{array}{l}\text { S1 Pend. } \\
\text { Kristen } \\
2011\end{array}$ & Tidak Layak \\
\hline & & $\begin{array}{l}\text { or } \\
\text { Kurikulu } \\
\mathrm{m}\end{array}$ & & $\begin{array}{ll}1 & \text { Indra Friatna } \\
6 & \end{array}$ & $\begin{array}{l}\text { Guru } \\
\text { Seni } \\
\text { Lukis }\end{array}$ & $\begin{array}{l}\text { S1 Teknik } \\
\text { Informatika }\end{array}$ & Tidak Layak \\
\hline 5 & $\begin{array}{l}\text { Dra. Yohana } \\
\text { F. E. Haryuni }\end{array}$ & $\begin{array}{l}\text { Wali } \\
\text { Kelas V }\end{array}$ & $\begin{array}{l}\text { S1 Filsafat } \\
\text { Pend ' } 91\end{array}$ & Layak & $\begin{array}{l}\text { Kelas I- } \\
\text { VI }\end{array}$ & & \\
\hline & & $\begin{array}{l}\text { A \& \& } \\
\text { Koordinat } \\
\text { or } \\
\text { Kesiswaa }\end{array}$ & & $\begin{array}{lll}1 & \text { Ester } & \text { Ita } \\
7 & \text { Harianti } & \end{array}$ & $\begin{array}{l}\text { Wali } \\
\text { Kelas I C } \\
\& \\
\text { II C } \\
\end{array}$ & $\begin{array}{l}\text { S1 Theologi } \\
2005\end{array}$ & Tidak Layak \\
\hline & & $\mathrm{n}$ & & Natalia & Guru & S1 Theologi & Tidak Layak \\
\hline 6 & $\begin{array}{l}\text { Geraldus } \\
\text { Ibung }\end{array}$ & $\begin{array}{l}\text { Wali } \\
\text { Kelas IV }\end{array}$ & SPG 1988 & Layak 8 & $\begin{array}{l}\text { Agama } \\
\text { Kelas I-II }\end{array}$ & 2013 & \\
\hline & & & & $1 \quad$ Itawati & Wali & S1 Theologi & Tidak Layak \\
\hline 7 & $\begin{array}{l}\text { Agustina } \\
\text { Paryatmi }\end{array}$ & $\begin{array}{l}\text { Wali } \\
\text { Kelas I A }\end{array}$ & $\begin{array}{ll}\text { S1 } & \text { PGSD } \\
2014 & \end{array}$ & Layak 9 & $\begin{array}{l}\text { Kelas III } \\
\text { C }\end{array}$ & 2001 & \\
\hline & & $\&$ B & & 2 Kevin & Guru & S1 Seni & Tidak Layak \\
\hline 8 & $\begin{array}{l}\text { Herdina } \\
\text { Kristina }\end{array}$ & $\begin{array}{l}\text { Wali } \\
\text { Kelas IV } \\
\text { C } \\
\end{array}$ & $\begin{array}{ll}\text { S1 } & \text { PGSD } \\
2016 & \end{array}$ & Layak 0 William & $\begin{array}{l}\text { Seni } \\
\text { Musik } \\
\text { Kelas I- }\end{array}$ & Musik 2013 & \\
\hline 9 & $\begin{array}{l}\text { Dyah } \\
\text { Ratnasari }\end{array}$ & $\begin{array}{l}\text { Wali } \\
\text { Kelas VI } \\
\text { B } \\
\end{array}$ & $\begin{array}{l}\text { S1 Pend. } \\
\text { B.Indonesia } \\
2011 \\
\end{array}$ & Tidak Layak & $\begin{array}{l}\text { VI \& } \\
\text { Kelas } \\
\text { VIII SMP }\end{array}$ & & \\
\hline $\begin{array}{l}1 \\
0\end{array}$ & $\begin{array}{l}\text { Agus Stani } \\
\text { Pratiwi }\end{array}$ & $\begin{array}{l}\text { Guru } \\
\text { Seni Tari } \\
\text { Kelas I- } \\
\text { VI } \\
\end{array}$ & SMU ‘94 & $\begin{aligned} & \text { Tidak_Layak } \\
& 2 \text { Hendri Puji } \\
& 1 \text { Kristiawan }\end{aligned}$ & $\begin{array}{l}\text { Guru } \\
\text { Komputer } \\
\text { Kelas I- } \\
\text { VI }\end{array}$ & $\begin{array}{l}\text { S1 Ekonomi } \\
2014\end{array}$ & Tidak Layak \\
\hline $\begin{array}{l}1 \\
1\end{array}$ & $\begin{array}{l}\text { Eka } \\
\text { Kurniasih }\end{array}$ & $\begin{array}{l}\text { Guru } \\
\text { Bahasa } \\
\text { Inggris }\end{array}$ & $\begin{array}{l}\text { S1 Pend. } \\
\text { B.Inggris } \\
{ }^{\circ} 05\end{array}$ & \begin{aligned} & \multicolumn{2}{l}{ Tidak_Layak } \\
& 2 Ilham \\
& 2 Cahaya \\
&\end{aligned} & $\begin{array}{l}\text { VI } \\
\text { Guru } \\
\text { Bahasa }\end{array}$ & $\begin{array}{l}\text { S1 } \\
\text { Akuntansi }\end{array}$ & Tidak Layak \\
\hline
\end{tabular}




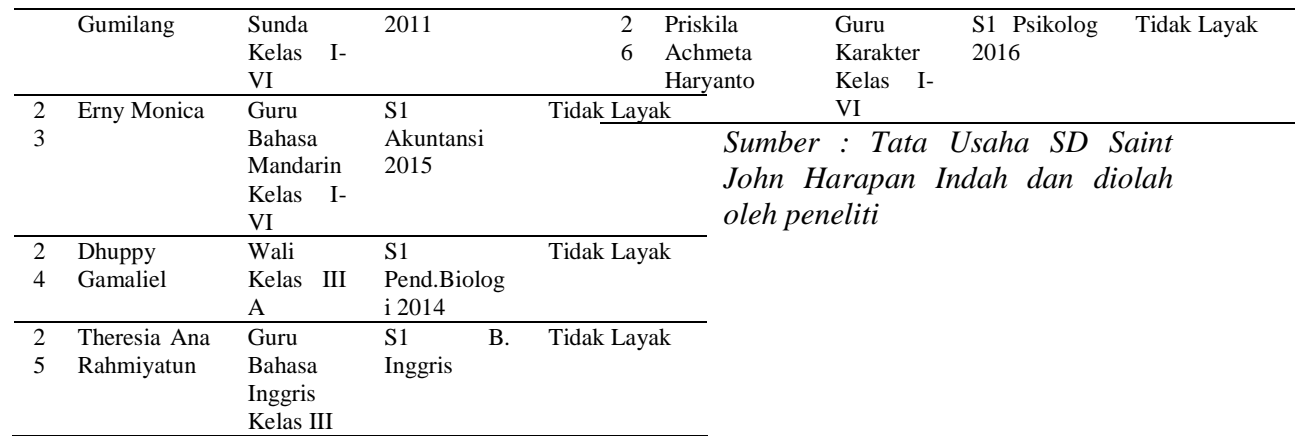

Dari data tabel 1.3 bisa pengolahan data primer dengan dilihat, bahwa $73 \%$ guru SD variabel rekrutmen.

Saint John Harapan Indah tidak

Berdasarkan data yang sudah layak mendapatkan TPP karena tidak memiliki ijazah PGSD dan hal yang lebih harus dikoreksi adalah bahwa beberapa dari mereka yang tidak memiliki ijazah PGSD adalah Wali Kelas. Sesuai aturan Permendikbud no.62 tahun 2013, guru yang sudah memiliki jabatan wajib PGSD atau mengikuti sertifikasi guru.

Kondisi tidak linear antara kompetensi pendidikan minimal yang dituntutkan dengan kewajiban jabatan memiliki dampak besar pada performa. Hal ini dapat dilihat dari data hasil survei pendahuluan yang peneliti lakukan di SD, SMP, dan SMA Saint John Harapan Indah. Berikut adalah hasil diolah oleh peneliti, dapat dilihat bahwa dari data survey pendahuluan diatas menunjukkan informasi terkait dengan variabel kompensasi dengan metode uji validitas skala Guttman. Menurut peneliti, terdapat masalah pada variabel rekrutmen di SD, SMP, dan SMA Saint John Harapan Indah. Hal ini ditunjukkan pada pernyataan nomor 2 (tentang perencanaan rekrutmen) dengan jawaban 'Tidak' sebanyak 60\%, pernyataan nomor 5 (tentang waktu pelaksanaan rekrutmen) dengan jawaban 'Tidak' sebanyak $76 \%$, dan pada pernyataan nomor 6 (tentang sumber sumber rekrutmen) 
dengan jawaban 'Tidak' sebanyak $68 \%$. Pernyataan 2,5 , dan 6 merupakan beberapa unsur penting yang harus diperhatikan oleh perusahaan dalam melaksanakan rekrutmen terkait dengan kinerja guru terhadap yayasan.

Selain variabel rekrutmen, sumber daya manusia juga membutuhkan aspek pelatihan untuk dapat memaksimalkan performa karyawan. Hal ini dibutuhkan karena mayoritas karyawan belum berpengalaman dan belum memperlihatkan kompetensi yang menjadi standar guru. Di sisi lain, pelatihan bertujuan agar karyawan baru lebih cepat dalam mengerti maksud dan tujuan perusahaan, sekaligus untuk mengasah dan memotivasi kemampuan karyawan atau guru sehingga menghasilkan kinerja yang baik. Pelatihan dapat diartikan sebagai proses peningkatan pengetahuan dan keterampilan karyawan yang mencakup tujuan pengubahan sikap sehingga karyawan dapat melakukan pekerjaannya lebih efektif.
Kondisi pelatihan guru di SD, SMP, dan SMA Saint John Harapan Indah menunjukkan proses manajerial yang belum maksimal. Peneliti membuktikan kondisi tersebut dengan melakukan survei pendahuluan di SD, SMP, dan SMA Saint John Harapan Indah. Berikut adalah hasil pengolahan data primer variabel pelatihan.

Dari data survei pendahuluan menunjukkan beberapa informasi terkait variabel kompensasi dengan metode uji validitas skala Guttman. Menurut peneliti, terdapat masalah pada variabel rekrutmen di SD, SMP, dan SMA Saint John Harapan Indah. Hal ini ditunjukkan pada pernyataan nomor 2 (tentang munculnya kreativitas kerja) dengan jawaban 'Tidak' sebanyak $88 \%$ dan pada pernyataan nomor 5 (tentang memberikan kontribusi kepada sesama karyawan dan organisasi) dengan jawaban 'Tidak' sebanyak $76 \%$. Pernyataan 2 dan 5 merupakan beberapa unsur penting yang harus diperhatikan oleh perusahaan

dalam 
melaksanakan pelatihan terkait dengan kinerja guru terhadap yayasan.

Kinerja pegawai biasa diartikan sebagai kemampuan pegawai dalam melakukan sesuatu keahlian tertentu. Kinerja pegawai sangatlah perlu, sebab dengan kinerja ini akan diketahui seberapa jauh kemampuan pegawai dalam melaksanakan tugas yang dibebankan kepadanya. Untuk itu diperlukan penentuan kriteria yang jelas dan terukur serta ditetapkan secara simultan yang dijadikan sebagai acuan. Kinerja sering juga diartikan sejauh mana seseorang telah memainkan baginya dalam melaksanakan strategi organisasi, baik dalam mencapai sasaran khusus yang berhubungan dengan peran perorangan dan atau dengan memperlihatkan kompetensi yang dinyatakan relevan bagi organisasi. Kinerja merupakan suatu konsep yang multi dimensional mencakup tiga aspek yaitu sikap (attitude), kemampuan (ability) dan prestasi (accomplishment).
Berdasarkan uraian di atas, penulis tertarik untuk mengadakan penelitian mengenai bagaimana pengaruh rekrutmen dan pelatihan terhadap kinerja guru di SD, SMP, dan SMA Saint John Harapan Indah, maka penulis mengambil judul: "PENGARUH REKRUTMEN DAN PELATIHAN TERHADAP KINERJA GURU DI SD, SMP, SMA SAINT JOHN HARAPAN INDAH DI KOTA BEKASI"

Perumusan

Masalah.

Berdasarkan latar belakang yang dikemukakan di atas, maka rumusan masalah yang di ajukan dalam penelitian ini adalah sebagai berikut: Apakah rekrutmen berpengaruh positif dan signifikan terhadap kinerja guru di SD, SMP, dan SMA Sekolah Kristen Saint John? (2) Apakah pelatihan berpengaruh positif dan signifikan terhadap kinerja guru di SD, SMP, dan SMA Sekolah Kristen Saint John? (3) Apakah rekrutmen dan pelatihan berpengaruh positif dan signifikan terhadap kinerja guru 
di SD, SMP, dan SMA Sekolah Kristen Saint John?

Tujuan dari penelitian ini adalah:

1. Untuk mengetahui apakah

rekrutmen berpengaruh positif dan signifikan terhadap kinerja guru di SD, SMP, dan SMA Sekolah Kristen Saint John.

\section{Untuk mengetahui} apakah

pelatihan berpengaruh positif dan signifikan terhadap kinerja guru di SD, SMP, dan SMA Sekolah Kristen Saint John.

3. Untuk mengetahui apakah rekrutmen dan pelatihan berpengaruh positif dan signifikan terhadap kinerja guru di SD, SMP, dan SMA Sekolah Kristen Saint John.

\section{METODE PENELITIAN A. Jenis Penelitian}

Penelitian ini menggunakan metode kuantitatif, yaitu yang menurut Sugiyono (2012:23) dikatakan metode kuantitatif karena data penelitian berupa angka-angka dan analisis menggunakan statistik. Penelitian kuantitatif menekankan pada pengujian teori-teori melalui pengukuran variabel-variabel penelitian dengan angka dan melakukan analisis data dengan prosedur statistik (Indriantoro, 2012:12).

\section{B. Populasi dan Sampel}

Objek penelitian yang akan diteliti adalah SD, SMP, dan SMA Sekolah Kristen Saint John Harapan Indah di Kota Bekasi. Penelitian ini merupakan penelitian kuantitatif menggunakan metode survey. Penelitian ini dilakukan dari bulan April hingga bulan Juni 2017. Populasi penelitian berjumlah 50 guru, sampel penelitian berjumlah 50 guru. Teknik pengambilan sampel adalan Non Probability Sampling dengan pengambilan sampel menggunakan sampel jenuh.

\section{Sumber Data}

Dalam penelitian ini data primer yang diperoleh peneliti melalui pengumpulan kuesioner yang berisi jawaban dari pernyataan-pernyataan peneliti 
yang diisi oleh guru di SD, SMP, dan SMA Sekolah Kristen Saint John Harapan Indah di Kota Bekasi yang menjadi responden dalam penelitian ini dan data sekunder merupakan data yang diperoleh peneliti dari Tata Usaha di SD, SMP, dan SMA Sekolah Kristen Saint John Harapan Indah di Kota Bekasi.

\section{Uji Validitas}

Menurut Raharjo (2014) Uji validitas merupakan cara untuk mengetahui ke-valid-an atau kesesuaian angket yang peneliti gunakan untuk memperoleh data dari para responden. Uji Validitas Product Momen Pearson

menggunakan mengkorelasikan Correlation menghubungkan antara masingmasing skor item dengan skor total yang diperoleh dalam penelitian. Dasar pengambilan keputusan dalam uji validitas adalah:

1. Jika nilai $r$ hitung $>$ nilai $r$ tabel, maka angket tersebut dinyatakan valid.

2. Jika nilai $r$ hitung $<$ nilai $r$ tabel, maka angket tersebut dinyatakan tidak valid.

\section{E. Uji Reliabilitas}

Uji reliabilitas menunjukkan sejauh mana instrumen dapat memberikan hasil pengukuran yang konsisten apabila pengukuran dilakukan berulangulang (Sudjana, 2005: 109). Dalam website qme binus juga dinyatakan bahwa jika nilai alpha > 0.6 artinya reliabilitas mencukupi (sufficient reliability), sementara jika alpha $>0.80$ ini mensugestikan seluruh item reliabel dan seluruh tes secara konsisten memiliki reliabilitas yang kuat. Atau adapula yang memaknakannya sebagai berikut: jika alpha > 0.90 maka reliabilitas sempurna. Jika alpha antara 0.80-0.90 maka reliabilitas tinggi. Jika alpha $0.60-0.80$ maka reliabilitas moderat. Jika alpha < 0.60 maka reliabilitas rendah. Jika alpha rendah, kemungkinan satu atau beberapa item tidak reliabel.

\section{F. Uji Asumsi Klasik}

Uji asumsi klasik adalah persyaratan statistik yang harus dipenuhi pada analisis regresi linear berganda yang berbasis ordinary least square (OLS). Jadi analisis regresi yang tidak 
berdasarkan OLS tidak memerlukan persyaratan asumsi klasik, misalnya regresi logistik atau regresi ordinal. Uji asumsi klasik yang sering digunakan yaitu uji multikolinearitas, uji heteroskedastisitas, uji normalitas, uji autokorelasi dan uji linearitas.

\section{G. Uji Normalitas}

Menurut Sarjono dan Winda dalam Maineldi, dkk (2014:9) uji normalitas bertujuan untuk mengetahui normal atau tidaknya suatu distribusi data. Pada dasarnya uji normalitas adalah membandingkan antara yang kita miliki dan data berdistribusi nomal yang memiliki mean dan standar deviasi yang sama dengan data kita. Uji normalias menjadi hal penting karena salah satu syarat pengujian parametric-test (uji parametrik) adalah data harus memiliki distribusi normal (atau berdistribusi normal).

\section{H. Uji Multikolinearitas}

Menurut

Sudarmanto (2013:224) uji multikolinearitas ini dimaksudkan untuk membuktikan atau menguji ada atau tidaknya hubungan yang linear antara variabel satu dengan variabel bebas lainnya. Untuk mendeteksi ada atau tidaknya multikolineritas di dalam model regresi dapat dilihat melalui nilai tolerance > 0,10 dan variance inflationfactor $(\mathrm{VIF} \leq 10)$.

\section{Uji Heteroskedastisitas}

Uji heterokedastisitas bertujuan menguji apakah dalam model regresi terjadi ketidaksamaan varians dari residual satu pengamatan ke pengamatan yang lain. Ada beberapa cara yang dapat dilakukan untuk melakukan uji heteroskedastisitas, yaitu uji grafik plot, uji park, uji glejser, dan uji white. Pengujian pada penelitian ini menggunakan uji glejser dan uji grafik plot antara nilai prediksi variabel dependen yaitu ZPRED dengan residualnya SRESID. Tidak terjadi heteroskedastisitas apabila tidak ada pola yang jelas, serta titik-titik menyebar di atas dan di bawah angka 0 pada sumbu Y (Ghozali, 2013: 139-143).

\section{J. Persamaan Regresi Linear Berganda}


Uji regresi linear berganda bertujuan untuk mengetahui besaran pengaruh variabel bebas (X1 dan X2) terhadap variabel terikat $(\mathrm{Y})$.

Rumus : $\mathrm{Y}=\mathrm{a}+\mathrm{bX} 1+\mathrm{bX} 2+\mathrm{e}$

Keterangan:

$\mathrm{Y}=$ Variabel Dependen

$\mathrm{a}=$ Konstanta

K. Uji Hipotesis

Menurut Akbar (2015), Pengujian Hipotesis adalah suatu prosedur yang dilakukan dengan tujuan memutuskan apakah menerima atau menolak hipotesis itu. Dalam pengujian hipotesis, keputusan yang di buat mengandung

ketidakpastian, artinya keputusan bias benar atau salah, sehingga menimbulkan risiko. Besar kecilnya risiko dinyatakan dalam bentuk probabilitas. Pengujian hipotesis merupakan bagian terpenting dari statistic inferensi (statistic induktif), karena berdasarkan pengujian tersebut, pembuatan keputusan atau pemecahan persoalan sebagai dasar penelitian lebih lanjut dapat terselesaikan.

1. Uji t
Uji $\mathrm{t}$ ini bertujuan untuk mengetahui pengaruh variabel bebas (X1 dan X2) terhadap variabel terikat (Y), serta mengetahui pengaruh mana yang lebih besar antara X1 dan X2 terhadap Y. Pengujian tersebut membandingkan antara 1 hitung dan 1 kritis. Menurut Priyanto (2009:50) t kritis dapat dicari pada tabel statistik pada signifikan 0.05 dengan $\mathrm{df}-\mathrm{n}-\mathrm{k}-$ 1 atau 50-2-1 = 47. Kemudian dimasukkan ke dalam rumus $=$ TINV $(0.05,47)=2.01174$. Menunjukkan bahwa $\mathrm{t}$ kritis atau t tabel adalah 2.01174. Apabila hasil perhitungan menunjukan :

1. Jika $\mathrm{t}$ hitung $\leq \mathrm{t}$ kritis $=\mathrm{H}_{\mathrm{o}}$ diterima. Artinya bahwa tidak adanya pengaruh antara variabel yang diuji dengan variabel terikat.

2. Jika $\mathrm{t}$ hitung $>\mathrm{t}$ kritis $=\mathrm{H}_{\mathrm{o}}$ ditolak. Artinya bahwa ada pengaruh antara variabel yang diuji dengan variabel terikat.

\section{Uji F}

Uji hipotesis ini bertujuan untuk mengetahui apakah variabel X1 dan variabel X2 secara bersama-sama 
mempengaruhi variabel $\mathrm{Y}$ atau tidak. Pengujian tersebut dilakukan dengan cara membandingkan F hitung dengan $F$ kritis. Menurut Priyanto (2009) F kritis dapat dicari pada tabel statistik pada signifikasi $0.05 \mathrm{df} 1=\mathrm{k}-1$ dan $\mathrm{df} 2=\mathrm{n}-\mathrm{k}$ ( $\mathrm{k}$ adalah jumlah variabel) kemudian masukan ke cell kosong pada excel ketik FINV $(0.05,2,47)=3.195$, menunjukkan bahwa $f$ kritis adalah 3.195.

\section{Uji Korelasi}

Uji koefisien korelasi digunakan untuk mengetahui seberapa kuat hubungan antara variabel independent secara bersama-sama terhadap variabel dependen. Nilai koefisien korelasi menurut Sugiyono (2012:260) berkisar antara -1 sampai dengan +1 yang kriteria pemanfaatannya di jelaskan sebagai berikut :

1. Jika nilai $r>0$, artinya telah terjadi hubungan yang linier positif, yaitu makin besar variabel $\mathrm{X}$ maka semakin besar variabel Y.
2. Jika nilai $r<0$, artinya telah terjadi hubungan yang linier negatif, yaitu semakin kecil nilai variabel $X$ maka semakin besar variabel $\mathrm{Y}$ atau sebaliknya semakin besar variabel $\mathrm{X}$ maka semakin kecil variabel $\mathrm{Y}$.

3. Jika nilai $r=0$, artinya tidak ada hubungan sama sekali antara variabel $\mathrm{X}$ dengan variabel Y.

Jika nilai $r=1$ atau $r=-$ 1 , telah terjadi hubungan linier sempurna, yaitu berupa garis lurus, sedangkan bagi $r$ yang mengarah kearah angka 0 maka garis semakin tidak lurus.

\section{Uji Koefisien Determinasi}

Koefisien determinasi $\left(\mathrm{R}^{2}\right)$ pada intinya mengukur seberapa jauh kemampuan model dalam menerangkan variasi variabel dependen. Nilai koefisien determinasi adalah antara nol dan satu. Nilai $R^{2}$ yang kecil berarti kemampuan variabelvariabel independen dalam menjelaskan variasi variabel dependen amat terbatas. Nilai yang mendekati satu berarti variabel-variabel independen memberikan hampir semua 
informasi yang dibutuhkan Kesesuaian

pendidikan, untuk memprediksi variasi

Kesesuaian pengalaman. variabel dependen (Ghozali, 2013: 97).

\section{Operasional Variabel}

Agar variabel-variabel itu dapat beroperasi dengan baik, maka diperlukan kegiatan operasionalisasi variabel. Adapun operasionalisasi variabel untuk penelitian ini adalah sebagai berikut:

1. Rekrutmen (X1)

Gary Dessler menyatakan bahwa merekrut karyawan adalah proses mengidentifikasi dan menarik orang untuk bekerja dalam sebuah organisasi (2011:201).

Rekrutmen memiliki tiga dimensi: perencanaan, analisis pekerjaan, dan sumber perekrutan. Dimensi Perencanaan Rekrutmen memiliki indikator: kejelasan aturan rekrutmen, kesesuaian pelaksanaan rekrutmen karena adanya permintaan manajer, kejelasan jumlah karyawan, kesesuaian persyaratan, dan kesesuaian waktu pelaksanaan rekrutmen. Dimensi Analisis pekerjaan dengan indikator:

Dimensi Sumber perekrutan dengan indikator: Pelaksanaan perekrutan calon karyawan berasal dari luar karyawan perusahaan, Pelaksanaan perekrutan calon karyawan dilakukan dengan menggunakan media masa, Informasi lowongan pekerjaan berasal dari rekomendasi

karyawan perusahaan.

2. Pelatihan (X2)

Pelatihan adalah bagian pendidikan yang menyangkut proses belajar untuk memperoleh dan meningkatkan keterampilan diluar sistem pendidikan yang lebih mengutamakan pada praktek dari pada teori (Rivai, 2005). Pelatihan memiliki empat dimensi: Dimensi Materi Pelatihan dengan indikator: Kelengkapan materi pelatihan, Metode Pelatihan, Metode pelatihan yang sesuai. Dimensi Pelatih / Instruktur dengan indikator: Kemampuan instruktur pelatihan. Dimensi Peserta Pelatihan dengan Kesesuaian keterampilan, indikator: Kemampuan peserta Kesesuaian kemampuan, pelatihan, Motivasi peserta 
pelatihan. Dimensi Sarana Pelatihan dengan indikator: Kelengkapan peralatan, Kondisi lingkungan,

Penyelenggara pelatihan.

3. Kinerja Karyawan

(Y)

Kinerja karyawan sebagai ungkapan seperti output atau hasil kerja, efisiensi serta efektivitas tenaga kerja (Gomes, 2003). Kinerja memiliki enam dimensi: Dimensi Kualitas Kerja dengan indikator: Ketepatan dalam menyelesaikan pekerjaan, Hasil kerja, Bisa diterima atas pekerjaan yang dilakukan.

Dimensi Produktivitas dengan indikator: Jumlah pekerjaan yang dihasilkan, Ketepatan dalam menyelesaikan pekerjaan. Dimensi Pengetahuan Pekerjaan dengan indikator: Ketermpilan yang dimiliki karyawan dalam mengerjakan Kemampuan yang dimiliki karyawan dalam mengerjakan pekerjaan. Dimensi Bisa diandalkan dengan indikator: Bisa diandalkan dalam pekerjaan, Tindak lanjut tugas atas pekerjaan yang dibebankan. Dimensi Kehadiran dengan indikator: Tepat waktu dalam kehadiran, Tepat waktu setelah beristirahat. Dimensi Kebebasan dengan indikator: Bekerja tanpa pengawasan.

\section{J. Model Penelitian}

Model Penelitian dibuat dari variabel-variabel yang sudah dijelaskan di atas. Pada penelitian ini, model penelitian bisa dilihat dibawah ini:

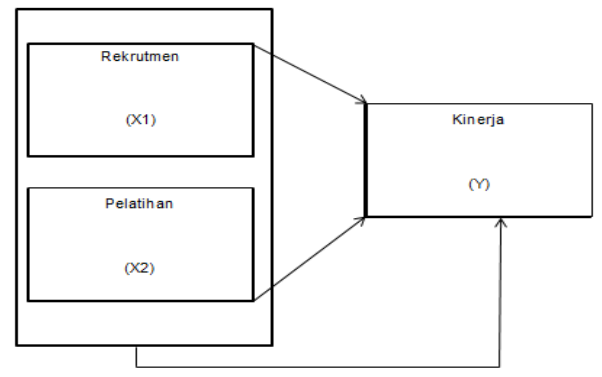

Gambar 1. Model Penelitian

\section{K. Hipotesis Penelitian}

Penjelasan dari model penelitian diatas adalah sebagai berikut: Dalam penelitian ini, peneliti membuat 3 hipotesis melalui variabel-variabel yang sudah dijelaskan sebelumnya. Adapun 3 hipotesis itu adalah : (1) Rekrutmen berpengaruh secara signifikan terhadap Kinerja; (2) Pelatihan berpengaruh secara signifikan 
terhadap Kinerjau; dan (3) Rekrutmen dan Pelatihan secara bersama-sama berpengaruh signifikan terhadap Kinerja.

III. HASIL

\section{PEMBAHASAN}

\section{A. Karakteristik responden}

Pengumpulan data dalam penelitian ini dilakukan melalui kuesioner yang disebarkan pada 50 guru di SMP dan SMA Saint John Harapan Indah dengan menggunakan teknik simple random sampling. Pengumpulan data ini dilakukan pada tahun 2017. Karakteristik yang ada dalam penelitian ini adalah jenis kelamin, lama bekerja dan latar belakang pendidikan pegawai tersebut.

\section{B. Jenis Kelamin}

\section{Jenis Kelamin}

Gambar 2. Jenis Kelamin

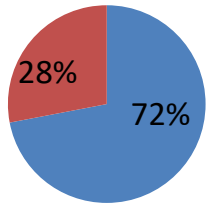

Berdasarkan jenis kelamin dari 50 orang yang dijadikan sebagai sampel dalam penelitian ini, menunjukkan bahwa responden yang berjenis kelamin laki-laki sebanyak 14 orang (28\%), sedangkan responden yang berjenis kelamin perempuan sebanyak 36 orang $(72 \%)$.

\section{Lama Bekerja}

\section{Lama Bekerja}

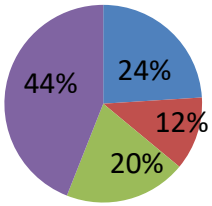

1-3 tahun

4-6 tahun

7-9 tahun

$\geq 10$ tahun

Berdasarkan lama bekerja dari 50 orang yang dijadikan sebagai sampel dalam penelitian ini, menunjukkan bahwa responden yang telah bekerja selama 1-3 tahun sebanyak 12 orang $(24 \%)$, responden yang telah bekerja selama 4-6 tahun sebanyak 6 orang (12\%), responden yang telah bekerja selama 7-9 tahun sebanyak 10 
orang (20\%) dan responden yang telah bekerja selama lebih dari 10 tahun sebanyak 22 orang (44\%). Dari data tersebut, maka dapat dilihat bahwa sebagian besar responden kuesioner adalah guru yang telah bekerja selama lebih dari 10 tahun.

\section{Latar \\ Pendidikan}

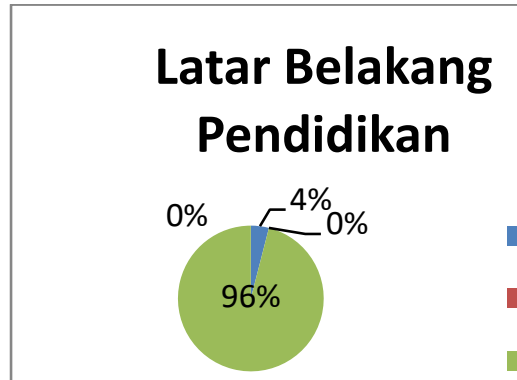

Gambar 4. Latar Belakang

Pendidikan

Berdasarkan latar belakang pendidikan dari 50 orang yang dijadikan sebagai sampel dalam penelitian ini, menunjukkan bahwa responden yang berlatar belakang pendidikan SMA sebanyak 2 orang (4\%), responden berlatar belakang pendidikan D3 sebanyak 0 orang $(0 \%)$, responden berlatar belakang pendidikan S1 sebanyak 48 orang (96\%) dan responden berlatar belakang pendidikan S2 sebanyak 0 orang $(0 \%)$. Dari data tersebut, maka dapat dilihat bahwa sebagian besar responden kuesioner adalah guru yang berlatar belakang pendidikan $\mathrm{S} 1$.

\section{E. Uji Validitas}

Hasil uji validitas variabel rekrutmen menunjukkan bahwa semua indikator yang diberikan dinyatakan valid.

\begin{tabular}{ccc}
\multicolumn{2}{c}{ Tabel 2. Uji Validitas Rekrutmen } \\
\hline Indikator & $\begin{array}{c}\text { Korelasi } \\
\text { Person }\end{array}$ & $\begin{array}{c}\text { r Tabel } \\
\text { N=30 }\end{array}$ \\
\hline RK1 & 0.540 & 0.279 \\
\hline RK2 & 0.494 & 0.279 \\
\hline RK3 & 0.501 & 0.279 \\
\hline RK4 & 0.593 & 0.279 \\
\hline RK5 & 0.762 & 0.279 \\
\hline RK6 & 0.412 & 0.279 \\
\hline RK7 & 0.679 & 0.279 \\
\hline RK8 & 0.454 & 0.279 \\
\hline RK9 & 0.557 & 0.279 \\
\hline RK10 & 0.366 & 0.279 \\
\hline RK12 & 0.535 & 0.279 \\
\hline RK13 & 0.336 & 0.279 \\
\hline RK14 & 0.400 & 0.279 \\
\hline RK15 & 0.533 & 0.279 \\
\hline RK15 & 0.570 & 0.279 \\
\hline RK16 & 0.535 & 0.279 \\
\hline RK17 & 0.610 & 0.279 \\
\hline Rekrutmen & 1.00 & 0.279 \\
\hline Hasil uji & validitas & variabel \\
pelatihan menunjukkan & bahwa \\
semua indikator yang diberikan \\
dinyatakan valid. & \\
\hline
\end{tabular}


Tabel 3. Uji Validitas Pelatihan

\begin{tabular}{ccc}
\hline Indikator & $\begin{array}{c}\text { Korelasi } \\
\text { Person }\end{array}$ & $\begin{array}{c}\text { r Tabel } \\
\mathbf{N = 3 0}\end{array}$ \\
\hline PL1 & 0.553 & 0.279 \\
\hline PL2 & 0.694 & 0.279 \\
\hline PL3 & 0.715 & 0.279 \\
\hline PL4 & 0.528 & 0.279 \\
\hline PL5 & 0.364 & 0.279 \\
\hline PL6 & 0.460 & 0.279 \\
\hline PL7 & 0.739 & 0.279 \\
\hline PL8 & 0.437 & 0.279 \\
\hline PL9 & 0.575 & 0.279 \\
\hline PL10 & 0.639 & 0.279 \\
\hline PL11 & 0.603 & 0.279 \\
\hline PL12 & 0.719 & 0.279 \\
\hline PL13 & 0.345 & 0.279 \\
\hline PL14 & 0.614 & 0.279 \\
\hline PL15 & 0.465 & 0.279 \\
\hline Pelatihan & 1.00 & 0.279 \\
\hline Hasil uji & validitas & variabel \\
kinerja menunjukkan & bahwa \\
semua indikator yang diberikan \\
dinyatakan valid.
\end{tabular}

Tabel 4. Uji Validitas Kinerja

\begin{tabular}{ccc}
\hline Indikator & $\begin{array}{c}\text { Korelasi } \\
\text { Person }\end{array}$ & $\begin{array}{c}\text { r Tabel } \\
\mathbf{N = 3 0}\end{array}$ \\
\hline KK1 & 0.701 & 0.279 \\
\hline KK2 & 0.687 & 0.279 \\
\hline KK3 & 0.718 & 0.279 \\
\hline KK4 & 0.509 & 0.279 \\
\hline KK5 & 0.745 & 0.279 \\
\hline KK6 & 0.639 & 0.279 \\
\hline KK7 & 0.695 & 0.279 \\
\hline KK8 & 0.435 & 0.279 \\
\hline KK9 & 0.623 & 0.279 \\
\hline KK10 & 0.754 & 0.279 \\
\hline KK11 & 0.635 & 0.279
\end{tabular}

\begin{tabular}{lcc}
\hline KK12 & 0.600 & 0.279 \\
\hline KK13 & 0.619 & 0.279 \\
\hline KK14 & 0.665 & 0.279 \\
\hline KK15 & 0.643 & 0.279 \\
\hline Kinerja & 1.00 & 0.279 \\
\hline Nilai total & korelasi & person \\
pada ketiga tabel uji validitas \\
menunjukkan nilai yang besar \\
dari nilai r tabel yaitu & 0.279 \\
sehingga semua indikator dalam \\
penelitian ini dinyatakan valid. \\
F. Uji Reliabilitas
\end{tabular}

Hasil uji reliabilitas seluruh variabel yang diberikan dinyatakan reliabel. Tabel 5. Uji Reliabilitas

Variabel Cronbach' Keteranga

\begin{tabular}{ccc} 
& s Alpha & $\mathrm{n}$ \\
\hline $\begin{array}{c}\text { Rekrutme } \\
\mathrm{n}\end{array}$ & 0.830 & Reliabel \\
\hline Pelatihan & 0.846 & Reliabel \\
\hline $\begin{array}{c}\text { Kinerja } \\
\text { Guru }\end{array}$ & 0.899 & Reliabel \\
\hline Tabel diatas & menunjukkan
\end{tabular}
seluruh variabel memiliki nilai Cronbach Alpha diatas 0.60, maka senua variabel di dalam penelitian ini dinyatakan relianel.

\section{G. Uji Normalitas}

Uji normalitas dilakukan untuk mengetahui apakah distribusi dari data merupakan distribusi normal atau tidak. Model regresi yang baik adalah model regresi yang memiliki 
distribusi data yang normal penelitian ini berasal dari ataupun mendekati normal. populasi yang berdistribusi Untuk melihat normal atau normal. tidaknya distribusi dari setiapsetiap variabel tersebut maka dapat dilakukan dengan melihat grafik normal probability

Normal P-P Plot of Regression Standardized Residual

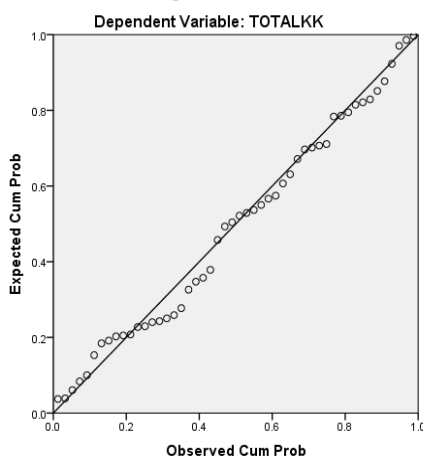

Gambar 5. Normal P-Plot

Uji normalitas dengan menggunakan normal probability plot mensyaratkan bahwa penyebaran data harus berada disekitar wilayah garis diagonal dan mengikuti arah garis diagonal. Berdasarkan gambar diatas dapat disimpulkan bahwa data dalam penelitian ini memenuhi syarat normal probability plot sehingga model regresi dalam penelitian memenuhi asumsi normalitas. Artinya data dalam

\section{H. Uji Multikolinearitas}

Uji

multikolinearitas

bertujuan untuk menguji ada atau tidaknya korelasi antara variabel independent (bebas) dan variabel dependent (terikat) dalam suatu model regresi. Uji multikolinearitas dalam penelitian ini dilakukan dengan melihat variance factor (VIF)

Tabel 6. Uji Multikolinearitas

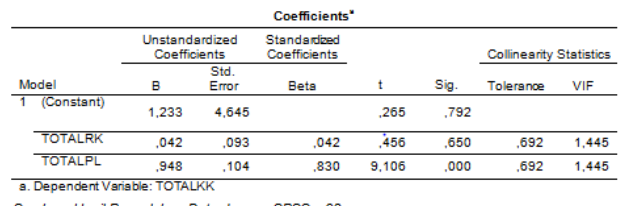

Sumber: Hasil Pengolahan Data dengan SPSS v. 23

Dalam uji multikolinearitas, jika nilai VIF $\leq 10$ maka tidak terdapat multikorelasi. Berdasarkan tabel di atas dapat dilihat bahwa VIF yaitu 1.445. Sehingga dapat disimpulkan bahwa tidak terdapat multikolinearitas dalam data penelitian ini, karena $(\mathrm{VIF} \leq 10)$ yaitu 1.445. Selain itu, di kolom tolerance menunjukkan angka 0.692. Yang berarti, tidak terdapat multikolinearitas dalam data penelitian ini, karena 
(Tolerance $\leq 0.1)$ yaitu 0.692 . Artinya bahwa antara variabel bebas, Rekrutmen (X1) dan Pelatihan (X2) tidak saling mengganggu atau mempengaruhi.

\section{Uji Heterokedastisitas}

Hasil uji heterokedastisitas bertujuan untuk menguji apakah dalam model regresi terjadi ketidaksamaan varian dari residual satu pengamatan ke pengamatan lain. Deteksi ada atau tidak adanya heterokedastisitas dapat dilakukan dengan melihat ada tidaknya adanya pola tertentu pada grafik scatterplot.

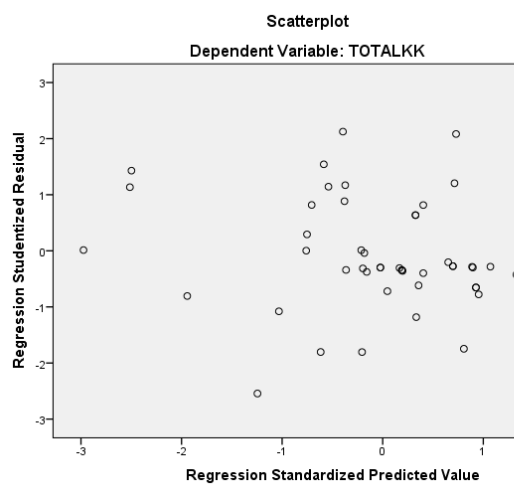

Gambar 6. Scatterplot

Dalam scatterplot diatas terlihat menyebar secara rata dari bagian atas hingga bawah, dengan demikian dapat disimpulkan bahwa tidak terjadi heterokedatisitas dalam model regresi ini.

J. Uji t

Uji $\mathrm{t}$ ini bertujuan untuk mengetahui pengaruh variabel bebas (X1 dan X2) terhadap variabel terikat (Y), serta mengetahui pengaruh mana yang lebih besar antara X1 dan X2 terhadap Y. Pengujian tersebut membandingkan antara $\mathrm{t}$ hitung dan $\mathrm{t}$ kritis. Menurut Priyanto (2009:50), $\mathrm{t}$ kritis dapat dicari pada tabel statistik pada signifikan 0.05 dengan df - n-k-1 atau 50-2-1 = 47 . Kemudian dimasukkan ke dalam rumus $=\operatorname{TINV}(0.05,47)$ $=2.01174$. Menunjukkan bahwa $\mathrm{t}$ kritis atau $\mathrm{t}$ tabel adalah 2.01174 .

\begin{tabular}{|c|c|c|c|c|c|}
\hline \multirow{2}{*}{ Coefficients $^{2}$} & \multicolumn{5}{|c|}{ Tabel 7. Uji $t$} \\
\hline & $\begin{array}{l}\text { Unstand } \\
\text { Coeffic }\end{array}$ & $\begin{array}{l}\text { lardized } \\
\text { cients }\end{array}$ & $\begin{array}{l}\text { Standardized } \\
\text { Coefficients }\end{array}$ & & \\
\hline Model & B & Std. Error & Beta & T & Sig. \\
\hline 1 (Constant) & 1,233 & 4,645 & & 265 & ,792 \\
\hline TOTALRK &, 042 & ,093 & ,042 & ,456 & ,650 \\
\hline TOTALPL & .948 &, 104 & .830 & 9,106 & .000 \\
\hline
\end{tabular}

Hasil dari Uji Hipotesis t tersebut adalah:

(1) Pada variabel Rekrutmen (X1) menunjukan $\mathrm{t}$ hitung adalah 0.456. Yang menunjukan 
bahwa $\mathrm{t}$ hitung $\leq \mathrm{t}$ kritis $=0.456$ $\leq$ 2.012. Hasil ini mengidentifikasikan bahwa variabel rekrutmen (X1) tidak berpengaruh secara signifikan terhadap kinerja guru (Y). Hal tersebut menunjukan bahwa hipotesis yang menyatakan rekrutmen berpengaruh secara signifikan terhadap kinerja guru ditolak. Pada variabel Pelatihan(X2) menunjukan $t$ hitung adalah 9.106. Yang menunjukan bahwa $\mathrm{t}$ hitung $\geq \mathrm{t}$ kritis $=9.106 \geq 2.012$. Hasil ini mengidentifikasikan bahwa variabel pelatihan (X2) berpengaruh secara signifikan terhadap varibel kinerja guru (Y). Hal tersebut menunjukan bahwa hipotesis

menyatakan pelatihan berpengaruh secara signifikan terhadap kinerja guru diterima.

(3) Koefisien variabel rekrutmen (X1) tidak berpengaruh secara signifikan terhadap variabel kinerja guru (Y). Hal ini dikarenakan tingkat signifikasi terhadap variabel rekrutmen (X1) sebesar 0.650 yang lebih besar dari 0.05 $(0.650>0.05)$. Dalam organisasi ini menunjukkan bahwa organisasi tersebut rekrutmen tidak berpengaruh secara signifikan terhadap kinerja guru melainkan faktor lain.

(4) Koefisien variabel pelatihan (X2) berpengaruh secara signifikan terhadap variabel kinerja guru (Y). Hal ini dikarenakan tingkat signifikasi terhadap variabel pelatihan (X2) sebesar 0.000 yang lebih kecil dari $0.05(0.000$ $<0.05)$.

Dari hasil diatas dapat kita simpulkan bahwa diantara kedua variabel bebas (X1 dan X2) hanya variabel pelatihan (X2) yang memiliki pengaruh yang signifikan terhadap kinerja guru (Y).

\section{K. Uji Regresi Linear Berganda}

Uji regresi linear berganda bertujuan untuk mengetahui besaran pengaruh variabel bebas (X1 dan X2) terhadap variabel terikat (Y). Pengujian tersebut dilakukan dengan menggunakan SPSS versi 23 dan diperoleh hasil sebagai berikut.

$\mathbf{Y}=\mathbf{a}+\mathbf{b X 1}+\mathbf{b X 2}+\mathbf{e}$ 
(1) $\mathrm{Y}=1,233+0.042 \mathrm{X} 1$ variabel rekrutmen (X1) yaitu $($ Pengaruh RK terhadap KK) $+0.948>0.042$.

\subsection{X2 (Pengaruh}

Terhadap KK) + e,

(2) Konstanta sebesar 1.233 menyatakan bahwa : jika nilai variabel rekrutmen (X1) dan pelatihan (X2) bernilai 0 , maka nilai variabel kinerja guru $(\mathrm{Y})$ adalah 1.233.

(3) Koefisien regresi variabel rekrutmen (X1) sebesar 0.042 artinya jika ada setiap penambahan (karena tanda +) satu nilai pada variabel rekrutmen (X1) akan memberikan kenaikan skor sebesar 0.042 .

(4) Koefisien regresi variabel pelatihan (X2) sebesar 0.948 artinya jika ada setiap penambahan (karena tanda + ) satu nilai pada variabel pelatihan (X2) akan memberikan kenaikan skor sebesar 0.948 .

(5) Pada kedua variabel bebas (X1 dan X2) yang menunjukkan bahwa memiliki pengaruh yang lebih besar adalah variabel pelatihan (X2) karena nilai konstanta variabel pelatihan (X2) lebih besar dari

\section{Uji T Lanjutan}

Karena variabel rekrutmen tidak berpengaruh secara signifikan pada kinerja, maka dilakukan uji t ulang dengan variabel pelatihan terhadap kinerja dengan memakai regresi linear sederhana. Uji regresi sederhana atau parsial dilakukan untuk mengetahui seberapa besar pengaruh hubungan antara variabel dependen dan independen secara terpisah Tabel 8. Uji T Lanjutan Coefficients $^{2}$

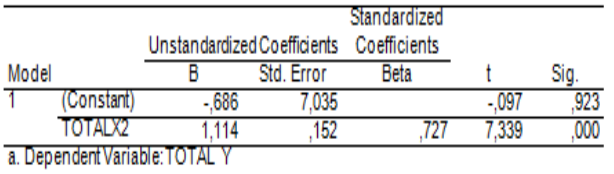

Koefisien regresi variabel pelatihan (X2) sebesar 1.114 artinya jika ada setiap penambahan (karena tanda +) satu nilai pada variabel pelatihan (X2) akan memberikan kenaikan skor sebesar 1.114. Koefisien variabel pelatihan (X2) berpengaruh secara signifikan terhadap variabel kinerja guru (Y). Hal ini dikarenakan tingkat signifikasi terhadap variabel pelatihan (X2) sebesar 0.000 
yang lebih kesil dari $0.05(0.000$ $<0.05)$.

\section{M.Uji F}

Uji hipotesis ini bertujuan untuk mengetahui apakah variabel X1 dan variabel X2 secara bersama-sama mempengaruhi variabel $\mathrm{Y}$ atau tidak. Pengujian tersebut dilakukan dengan cara membandingkan $\mathrm{F}$ hitung dengan $F$ kritis. Menurut Priyanto (2009) F kritis dapat dicari pada tabel statistik pada signifikasi $0.05 \mathrm{df} 1=\mathrm{k}-1$ dan $\mathrm{df} 2=\mathrm{n}-\mathrm{k}$ ( $\mathrm{k}$ adalah jumlah variabel) kemudian masukan ke cell kosong pada excel ketik FINV $(0.05,2,47)=3.195$, menunjukkan bahwa $f$ kritis adalah 3.195.

Tabel 9. Uji F

\begin{tabular}{|c|c|c|c|c|c|}
\hline Model & $\begin{array}{c}\text { Sum of } \\
\text { Squares }\end{array}$ & Df & Mean Square & $F$ & Sig. \\
\hline 1 Regression & 1445,373 & 2 & 722,687 & 63,381 & $.000^{\circ}$ \\
\hline $\begin{array}{l}\text { Resicual } \\
\text {. }\end{array}$ & 535,907 & 47 & 11,402 & & \\
\hline Total & 1981,280 & 49 & & & \\
\hline
\end{tabular}

$$
\geq \quad \begin{array}{ccc}
F \text { hitung } \geq F \text { kritis }=63.381 \\
3.195 . \quad \text { Hal } \quad \text { ini }
\end{array}
$$
mengidentifikasikan bahwa $\mathrm{H}_{\circ}$ ditolah yang mengartikan bahwa variabel independen (X1 dan X2) secara bersama-sama memiliki pengaruh yang signifikan terhadap variabel dependen (Y). Dari signifikansi diketahui angka signifikansi $0.00<0.05$, maka bisa ditarik kesimpulan bahwa variabel independen (X1 dan X2) secara simultan memiliki pengaruh yang signifikan terhadap variabel dependen $(\mathrm{Y})$.

\section{N. Uji Korelasi}

Uji korelasi parsial dilakukan untuk mengetahui seberapa besar hubungan antara variabel dependen dengan variabel independen secara terpisah. Di dalam sebuah penelitian besarnya pengaruh variabel independen yaitu rekrutmen (X1) dan pelatihan (X2) secara parsial terhadap variabel kinerja guru (Y).

\section{Tabel 10. Uji Korelasi}

\begin{tabular}{llrrr}
\hline \multicolumn{4}{c}{ Correlations } \\
\\
\hline
\end{tabular}

dapat dilihat bahwa seberapa besar tingkat hubungan dari 
variabel independen secara parsial atau individual terhadap variabel dependen. Hasil uji korelasi adalah sebagai berikut (1) Variabel rekrutmen (X1) memiliki nilai koefisien sebesar 0.502 terhadap variabel kinerja guru (Y), menurut Ridwan (2005:136) variabel rekrutmen (X1) memiliki tingkat hubungan yang cukup kuat. Korelasi ini juga memiliki signifikansi yang baik karena $0.00<0.05$. (2) Variabel pelatihan memiliki nilai koefisien sebesar 0.853 terhadap variabel kinerja guru (Y), menurut Ridwan (2005:136) variabel rekrutmen (X2) memiliki tingkat hubungan yang sangat kuat. Korelasi ini juga memiliki signifikansi yang baik karena $0.00<0.05$.

O. Uji Determinasi X1, X2 terhadap Y

Uji determinasi digunakan untuk mengetahui seberapa besar presentase pengaruh kedua variabel independen secara simultan terhadap variabel dependen.

Tabel 11. Uji DeterminasI X1, X2 - Y

\begin{tabular}{lrrrrr}
\multicolumn{6}{c}{ Model Summary } \\
\hline Model & $R$ & R Square & $\begin{array}{c}\text { Adjusted R } \\
\text { Square }\end{array}$ & $\begin{array}{r}\text { Std. Error of } \\
\text { the Estimate }\end{array}$ \\
\hline 1 &, $731^{\circ}$ &, 534 & 515 & 5,94661 \\
\hline a. Predictors: (Constant), TOTALX2, TOTALX1 & \\
Sumber : Hasil Pengolahan Data dengan SPSS v.23
\end{tabular}

Nilai R2 atau koefisien determinasi sebesar $53.4 \%$ yang berarti besar pengaruh Variabel Rekrutmen dan Pelatihan terhadap Variabel Kinerja Guru, sedangkan sisanya sebesar $46.6 \%$ ditentukan oleh faktorfaktor lain.

\section{P. Uji Determinasi X2}

\section{terhadap Y}

Uji determinasi parsial $\mathrm{X} 2$ terhadap $\mathrm{Y}$ dilakukan karena temuan fakta X1 tidak memiliki pengaruh yang signifikan terhadap Y sesuai dengan hasil uji t.

Tabel 12. Uji Determinasi X2 - Y

\begin{tabular}{llccr}
\multicolumn{6}{c}{ Model Summary } \\
\hline Model & R & R Square & $\begin{array}{c}\text { Adjusted R } \\
\text { Square }\end{array}$ & $\begin{array}{c}\text { Std. Error of } \\
\text { the Estimate }\end{array}$ \\
\hline 1 &, $727^{\star}$ & 529 &, 519 & 5,92006 \\
\hline a. Predictors: (Constant), TOTALX2 \\
Sumber: Hasil Pengolahan Data dengan SPSS v.23
\end{tabular}

Nilai R2 atau koefisien determinasi sebesar $52.9 \%$ yang berarti besar pengaruh Variabel Rekrutmen dan Pelatihan terhadap Variabel Kinerja Guru, sedangkan sisanya sebesar $47.1 \%$ ditentukan oleh faktorfaktor lain. 


\section{SIMPULAN}

Berdasarkan hasil dari analisis penelitian pembahasan, maka disimpulkan beberapa sebagai berikut:

(1) Tidak terdapat pengaruh signifikan antara rekrutmen (X1) terhadap kinerja (Y) guru di SD, SMP, dan SMA Saint John Harapan Indah. Hal ini ditunjukkan dengan nilai $t$ hitung $\leq \mathrm{t}$ kritis $=0,456 \leq 2,012$ dan nilai signifikansi $\geq 0,05$ yaitu sebesar $0,650 \geq 0,05$. Dibutuhkan penelitian lebih lanjut untuk mengetahui variabel lain yang berpengaruh signifikan terhadap kinerja.

(2) Terdapat pengaruh signifikan antara kompensasi (X2) terhadap kinerja (Y) guru di SD, SMP, dan SMA Saint John Harapan Indah. Hal ini ditunjukkan dari uji t, dimana hasil $\mathrm{t}$ hitung $\geq \mathrm{t}$ kritis $=9,106 \geq$ 2,012 , dengan nilai signifikansi $\leq 0,05$ yaitu sebesar $0,000 \leq$ 0,05 .

(3) Terdapat pengaruh signifikan antara lingkungan kerja (X1) dan kompensasi (X2) secara bersama-sama atau simultan terhadap kinerja (Y) guru di SD, SMP, dan SMA Saint John Harapan Indah. Hal ini telah dibuktikan melalui hasil uji F dimana Fhitung dari kedua variabel independen yaitu rekrutmen (X1) dan pelatihan (X2) memiliki nilai Fhitung sebesar 63,381, dan nilai $P$ value (significant) menunjukan nilai sebesar 0,000. Hal ini menunjukan bahwa $\mathrm{F}$ hitung $\geq \mathrm{F}$ kritis $=63,381 \geq 3,195$. dan $0,000 \leq 0,05$.

\section{DAFTAR RUJUKAN}

Akbar, Aliansyah. "StatistikaPengujian Hipotesis". 2015. [Online]. Diakses 18 Januari 2017, dari http://sman3subang.sch.id/st atistika-pengujianhipotesis/.

Ghozali, Imam. (2013). Aplikasi Analisis Multivariat dengan Program IBM SPSS 21. Edisi 7, Badan Penerbit Universitas Diponegoro, Semarang.

Gomes, Faustino Cardoso. (2003). Manajemen Sumber Daya Manusia. Yogyakarta: Penerbit Andi.

Indriantoro, Nur dan Bambang Supomo. (2011). Metodologi Penelitian 
Bisnis Untuk Akuntansi Dan Manajemen, Edisi Pertama. Yogyakarta: BPFE.

Raharjo, Sahid. (2014). "SPSS Indonesia (olah data statistik dengan program SPSS) : cara melakukan uji validitas product momen dengan SPSS". [online]. Diakses 24 Juni 2017 dari spssindo.blogspot.com/2014 /01/uji-validitas-productmomen-spss [29 September 2014].

Rivai, Veithzal. (2005).

Manajemen Sumber Daya Manusia untuk Perusahaan, dari Teori ke Praktik. Jakarta: PT. Raja Grafindo Persada.

Sudarmanto, Gunawan. (2013).

Statistik Terapan Berbasis

Komputer dengan Program

IBM SPSS Statistics 19.

Jakarta: Mitra Wacana

Media.

Sugiyono. (2012). Memahami

Penelitian Kuantitatif.

Bandung: Alfabeta. 